\title{
NEURAMINIDASE PRODUCTION BY BACTEROIDACEAE
}

\author{
A. G. Fraser and R. Brown \\ Department of Bacteriology, Medical School, University of Edinburgh, Teviot Place, \\ Edinburgh EH8 $9 A G$
}

SUMmaRY. The production of neuraminidase (EC 3.2.1.18) by 77 strains of Bacteroidaceae was investigated by techniques previously used to study neuraminidase production by clostridia. Conditions for culture and assay of Bacteroides fragilis neuraminidase were characterised. The enzyme is predominantly cell associated; it is not calcium dependent and the $p \mathrm{H}$ optimum for its production is $c .4 \cdot 5$.

Most neuraminidase-positive Bacteroides strains produced the enzyme well in the test media but a few strains failed to produce it consistently in one or other of the media. Because of these occasional variations, strains were grown and tested in at least two media before being defined as neuraminidase negative.

Within the $B$. fragilis group of species, B. fragilis, B. vulgatus, $B$. distasonis, $B$. ovatus, $B$. thetaiotaomicron and $B$. variabilis were neuraminidase positive while $B$. eggerthii, $B$. uniformis and $B$. splanchnicus were negative. Two subspecies of $B$. melaninogenicus (ss. melaninogenicus and ss. levii) were positive but the other (ss. intermedius) was negative. Strains of $B$. oralis and $B$. bivius produced the enzyme while $B$. ruminicola, $B$. disiens, $B$. asaccharolyticus and $B$. corrodens did not. The microaerophilic $B$. ochraceus were also positive. None of the Fusobacterium or Leptotrichia species tested produced neuraminidase.

Our results for neuraminidase production are consistent for all strains of each species examined and we suggest that tests for neuraminidase production would be a valuable addition to biochemical tests currently used in taxonomic studies of the Bacteroidaceae.

\section{INTRODUCTION}

The importance of the Bacteroides-Fusobacterium group of gram-negative anaerobic bacilli as significant pathogens in various infections has become increasingly apparent with recent improvements in methods for their isolation and identification (Finegold, 1977). Little is known of their mechanisms of pathogenicity, and the biochemical attributes of the different species are still being defined.

Neuraminidases (EC 3.2.1.18) are produced by many species of aerobic and 
anaerobic bacteria (see Müller, 1974). The enzyme is thought to play a significant role in infection with influenza virus and other myxoviruses (Drzeniek, 1972; Rosenberg and Schengrund, 1976) and it has been suggested that it may also be a virulence factor for some pathogenic bacteria (Collee, 1965; Müller, 1974).

Müller and Werner (1970a and $b$ ) reported production of neuraminidase by some Bacteroides species and argued that the enzyme had a role in pathogenesis. We have previously reported studies of production of neuraminidase by clostridia (Fraser and Collee, 1975; Fraser, 1978) and have now extended these studies to a range of well characterised strains representing the major species of gram-negative non-sporing anaerobic bacilli.

\section{MATERIALS AND METHODS}

Bacterial strains. Many of the strains were characterised in detail in this laboratory and described by Duerden, Holbrook, Collee and Watt (1976) or Deacon, Duerden and Holbrook (1978). The other strains studied were as follows: Bacteroides eggerthii NCTC11155, B. splanchnicus NCTC10825 and NCTC10826, B. asaccharolyticus NCTC 9337 and Fusobacterium varium NCTC10560; these were obtained from the National Collection of Type Cultures, Central Public Health Laboratory, Colindale Avenue, London NW9 5HT. B. uniformis VPI11227, B. variabilis VPI11368 and B. melaninogenicus ss. levii VPI3300 were obtained from Dr Lillian V. Holdeman, Virginia Polytechnic Institute and State University, Blacksburg, Virginia 24060 , USA. B. oralis VPI8906D and VPI9958, B. bivius VPI5540, VPI6318, VPI6822 and VPI7880, and $B$. disiens VPI7852 and VPI8057 were provided by Dr Ella M. Barnes, Agricultural Research Council, Food Research Institute, Colney Lane, Norwich NOR 7OF. B. ruminicola strains B38024, B38080 and B56029 were provided by Dr T. Mitsuoka, Animal Pathology Laboratory, Institute of Physical and Chemical Research, Wako, Saitama 351, Japan. B. corrodens strains 143A and 151RV were provided by Dr A.L. James, Department of Chemistry, Faculty of Science and Technology, Newcastle upon Tyne Polytechnic. The GNAB and WPH strains were isolated from various sites in healthy adults in this laboratory, or from clinical material by colleagues in the diagnostic laboratories in the Bacteriology Departments of the Royal Infirmary and the Western General Hospital, Edinburgh. All strains were identified to species level by the methods described by Duerden et al. (1976).

Culture media and method of anaerobic culture. Cooked-meat broth (CMB), 5\% proteose peptone water broth (PPW5) and Todd-Hewitt broth (THB) were prepared as described by Fraser (1978). Thioglycollate broth (TGB) was prepared according to the manufacturer's recommendations (Thioglycollate Medium, fluid, without dextrose or Eh indicator, code 11727; BBL, Becton Dickinson UK Ltd, York House, Empire Way, Wembley, Middlesex HA9 0PS) with the addition of $0.25 \%$ yeast extract (Oxoid) and $0.25 \%$ sodium succinate $(\mathrm{BDH})$ to improve growth of Bacteroides strains. Digest broth (DB) was prepared as described by Cruickshank et al. (1975) but with best beef steak in place of horse flesh; the $\mathrm{NaHCO}_{3}$ was omitted and the final $p \mathrm{H}$ adjusted with $\mathrm{NaOH}$ to 7.4-7.6 before sterilisation by autoclaving. PPY broth medium was as described by Deacon $e t$ al. (1978). The BM broth medium used in this study was prepared as described by Deacon et al. (1978) but $0.25 \%$ sodium succinate was added and horse serum omitted.

CMB was used without added growth factors but all other media were supplemented with haemin and menadione as a routine; in addition, cysteine hydrochloride and $\mathrm{Na}_{2} \mathrm{CO}_{3}$ were added to PPY and BM media. Solutions of these supplements were sterilised by filtration and added aseptically to the steamed media just before inoculation as described by Deacon et al. (1978). The final concentrations were: haemin, $5 \mu \mathrm{g} / \mathrm{ml}$; menadione, $1 \mu \mathrm{g} / \mathrm{ml}$; cysteine hydrochloride, $0.075 \%(\mathrm{w} / \mathrm{v})$; and $\mathrm{Na}_{2} \mathrm{CO}_{3}, 0.04 \%$ (w/v). 
Anaerobic culture methods were those described by Fraser and Smith (1975). Cultures were prepared from lyophilised stock and maintained in CMB. For standard tests, an inoculum of $0 \cdot 2$ $\mathrm{ml}$ of a 48-h anaerobic culture in CMB incubated at $37^{\circ} \mathrm{C}$ was added to $10 \mathrm{ml}$ of steamed medium and incubated anaerobically at $37^{\circ} \mathrm{C}$ for $48 \mathrm{~h}$. Growth was estimated visually and recorded as ,,,++++++ \pm or - as described by Fraser (1978). Incubation was continued to $96 \mathrm{~h}$ to improve growth when there was $<+$ turbidity at $48 \mathrm{~h}$.

Preparation of cell extracts. The $48-\mathrm{h}$ or $96-\mathrm{h}$ cultures were centrifuged $(800 \mathrm{~g}$ for $60 \mathrm{~min}$ at $4^{\circ} \mathrm{C}$ ). If the culture supernates were to be tested, $5-\mathrm{ml}$ samples of the centrifuged supernates were removed and stored at $-20^{\circ} \mathrm{C}$. The rest of the supernate was then removed from the packed cell deposit and the cells from the $10 \mathrm{ml}$ culture were resuspended in $2 \mathrm{ml}$ of sterile normal saline. The resuspended cells were subjected to ultrasonic disintegration for 15-20 min in an ice bath (Fraser and Collee, 1975) and these uncentrifuged cell extracts were stored at $-20^{\circ} \mathrm{C}$ until assayed for neuraminidase.

A more concentrated bulk cell extract was prepared for tests of the effects of $p \mathrm{H}$ and $\mathrm{Ca}^{2+}$ on neuraminidase activity of $B$. fragilis NCTC 9344 . An inoculum of $2 \mathrm{ml}$ of a $48-\mathrm{h}$ CMB culture was added to $200 \mathrm{ml}$ of PPW5 broth and incubated anaerobically at $37^{\circ} \mathrm{C}$ for $48 \mathrm{~h}$. After centrifugation, the packed cell deposit was resuspended in $5 \mathrm{ml}$ of sterile normal saline and disrupted by ultrasonic vibration; the uncentrifuged cell extract was stored at $-20^{\circ} \mathrm{C}$.

Assay for neuraminidase activity. Human glycoprotein substrate FVII (Fraser and Smith, 1975) was used at a final concentration of $140-170 \mu \mathrm{g} \mathrm{N}$-acetyl neuraminic acid (NANA)/ml reaction mixture (Fraser, 1978).

The standard assay procedures used by Fraser (1978) were followed. Tests for neuraminidase activity were first incubated for $60 \mathrm{~min}$ before assay for free NANA; when the 60 -min assay showed little or no activity, tests were incubated for $24 \mathrm{~h}$ to demonstrate the presence or absence of detectable neuraminidase. Test spectrophotometric readings $\left(E_{549}\right)$ were corrected by subtraction of the sum of the values for separate enzyme and substrate controls.

The corrected results of neuraminidase assays were graded as follows: +++ , high values in 60 -min assays $\left(E_{549}>0.5\right)$; ++ , moderate NANA release clearly demonstrable in 60 -min assays $\left(E_{549}>0 \cdot 1\right) ;+$, neuraminidase not demonstrable in 60 -min assays but high values $\left(E_{549}>0.5\right)$ in 24 -h assays; \pm , low values $\left(E_{549}<0.5\right.$ but $\left.>0.05\right)$ in 24 -h assays and absorption peak clearly shown at $549 \mathrm{~nm}$; - no peak at $549 \mathrm{~nm}$ demonstrable in $24-\mathrm{h}$ assays.

Tests that gave low values $\left(E_{549}<0 \cdot 5\right)$ in 24 -h neuraminidase assays were routinely examined to confirm that the absorption peak was at $549 \mathrm{~nm}$ (Fraser, 1978) and at least one test from each neuraminidase-positive species was also examined in this manner, whether the assay values were high or low. Culture products that gave very low values or negative results in 24 -h neuraminidase assays $\left(E_{549}<0.5\right)$ were further examined to determine whether destruction of NANA by $\mathrm{N}$-acetyl neuraminic acid-aldolase (NAN-aldolase, EC 4.1.3.3) might be interfering with the 24-h neuraminidase assay (Fraser, 1978).

Studies of the effect of $\mathrm{pH}$ on the neuraminidase of $B$. fragilis. Neuraminidase assays were performed in a range of sodium-acetate buffers as described by Fraser and Smith (1975). The reaction mixture of $1.0-\mathrm{ml}$ volume consisted of: $0.1 \mathrm{ml}$ of the bulk cell extract of $B$. fragilis NCTC9344 (see above) diluted 1 in 40 in distilled water; $0.65 \mathrm{ml}$ of the appropriate acetate buffer; and $0.25 \mathrm{ml}$ of substrate FVII diluted in distilled water to give a final concentration in the reaction mixture of $160 \mu \mathrm{g} \mathrm{NANA} / \mathrm{ml}$. Separate enzyme and substrate controls were prepared at each $p \mathrm{H}$ value. Tests and controls were incubated at $37^{\circ} \mathrm{C}$ before the assay for NANA.

The $p \mathrm{H}$ values shown in the figure are the initial values for the buffers added to the tests. Separate measurements were made of the initial $p \mathrm{H}$ values in sample reaction mixtures prepared with equivalent proportions but in 3-ml total volumes.

Effect of $\mathrm{Ca}^{2+}$ and EDTA on the neuraminidase of $B$. fragilis. Neuraminidase assays in the presence of added $\mathrm{Ca}^{2+}$ or EDTA were performed as described by Fraser (1978). The test enzyme preparation was the bulk cell extract of $B$. fragilis NCTC9344 (see above) diluted 1 in 40 in acetate buffer, $p \mathrm{H} 5 \cdot 1$. Samples of the enzyme were mixed with buffer containing $\mathrm{Ca}^{2+}$ or EDTA and held at $37^{\circ} \mathrm{C}$ for $30 \mathrm{~min}$ before addition of substrate FVII and the start of the neuraminidase assay. Separate enzyme and substrate control tubes also contained $\mathrm{Ca}^{2+}$ or EDTA. 


\section{RESULTS}

Production of neuraminidase by Bacteroides fragilis NCTC9344

Table I records the production of neuraminidase by $B$. fragilis strain NCTC9344 in 48-h cultures in various fluid media. The culture supernates contained small amounts of enzyme activity that could be detected when the incubation time of the assays was prolonged to $24 \mathrm{~h}$. Cell extracts prepared from the same cultures contained larger amounts of neuraminidase that gave high assay values $\left(E_{549}\right)$ in 60 -min assays. Neither the culture supernates nor the cell extracts had significant NAN-aldolase activity that might interfere with the assay for NANA released by neuraminidase.

The organism grew adequately in all the media tested. Growth was least good in TGB and there were difficulties in centrifuging this culture because it contains a low concentration of agar. DB, PPW5 and BM broth media were chosen for further studies of neuraminidase production by Bacteroides species.

\section{Effect of $\mathrm{pH}$ and $\mathrm{Ca}^{2+}$ on neuraminidase of $\mathrm{B}$. fragilis NCTC9344}

A more concentrated bulk cell extract was prepared from a 200-ml PPW5 culture of $B$. fragilis strain NCTC9344 for studies of the effect of $p \mathrm{H}$ and $\mathrm{Ca}^{2+}$ on the enzyme. The figure shows the results of 30 -min neuraminidase assays in acetate buffers at different $p \mathrm{H}$ values. The assay values were corrected by subtraction of the values obtained in separate substrate and enzyme controls at each $p \mathrm{H}$ value; the enzyme controls were constant but the substrate controls were higher at low $p \mathrm{H}$ values.

The figure shows the $p \mathrm{H}$ optimum for $B$. fragilis neuraminidase with substrate FVII to be about $4 \cdot 2$. Acetate buffer at $p \mathrm{H} 5 \cdot 1$ is used in the standard assay (Fraser, 1978); this $p \mathrm{H}$ allows good neuraminidase activity and this

TABLE I

Production of neuraminidase by Bacteroides fragilis NCTC9344 in various culture media

\begin{tabular}{|c|c|c|c|}
\hline \multirow{2}{*}{$\begin{array}{l}\text { Culture } \\
\text { medium* }\end{array}$} & \multirow{2}{*}{$\begin{array}{l}\text { Degree of } \\
\text { growth } \dagger\end{array}$} & \multicolumn{2}{|c|}{$\begin{array}{c}\text { Relative amount of } \\
\text { neuraminidase } \\
\text { activity in culture product } \neq \text { : }\end{array}$} \\
\hline & & culture supernate & cell extract \\
\hline $\begin{array}{l}\text { DB } \\
\text { PPW5 } \\
\text { BM } \\
\text { CMB } \\
\text { PPY } \\
\text { TGB } \\
\text { THB }\end{array}$ & $\begin{array}{r}+++ \\
++ \\
++ \\
+++ \\
++ \\
+ \\
+++\end{array}$ & $\begin{array}{l} \pm \\
\pm \\
\pm \\
\pm \\
\pm \\
+ \\
\pm\end{array}$ & $\begin{array}{l}++ \\
+++ \\
+++ \\
+++ \\
+++ \\
+++ \\
+++\end{array}$ \\
\hline
\end{tabular}

* DB = Digest broth; $\mathrm{PPW} 5=$ proteose peptone water; $\mathrm{BM}=\mathrm{BM}$ medium; $\mathrm{CMB}=$ cooked-meat broth; PPY = PPY medium; TGB = thioglycollate broth; THB = Todd-Hewitt broth.

$\dagger$ See Methods for assessment of growth.

$\ddagger$ Supernates of 48 -h cultures tested in 24 -h assays; cell extracts from the same cultures tested in $60-\mathrm{min}$ assays. See methods for grading of neuraminidase activity 


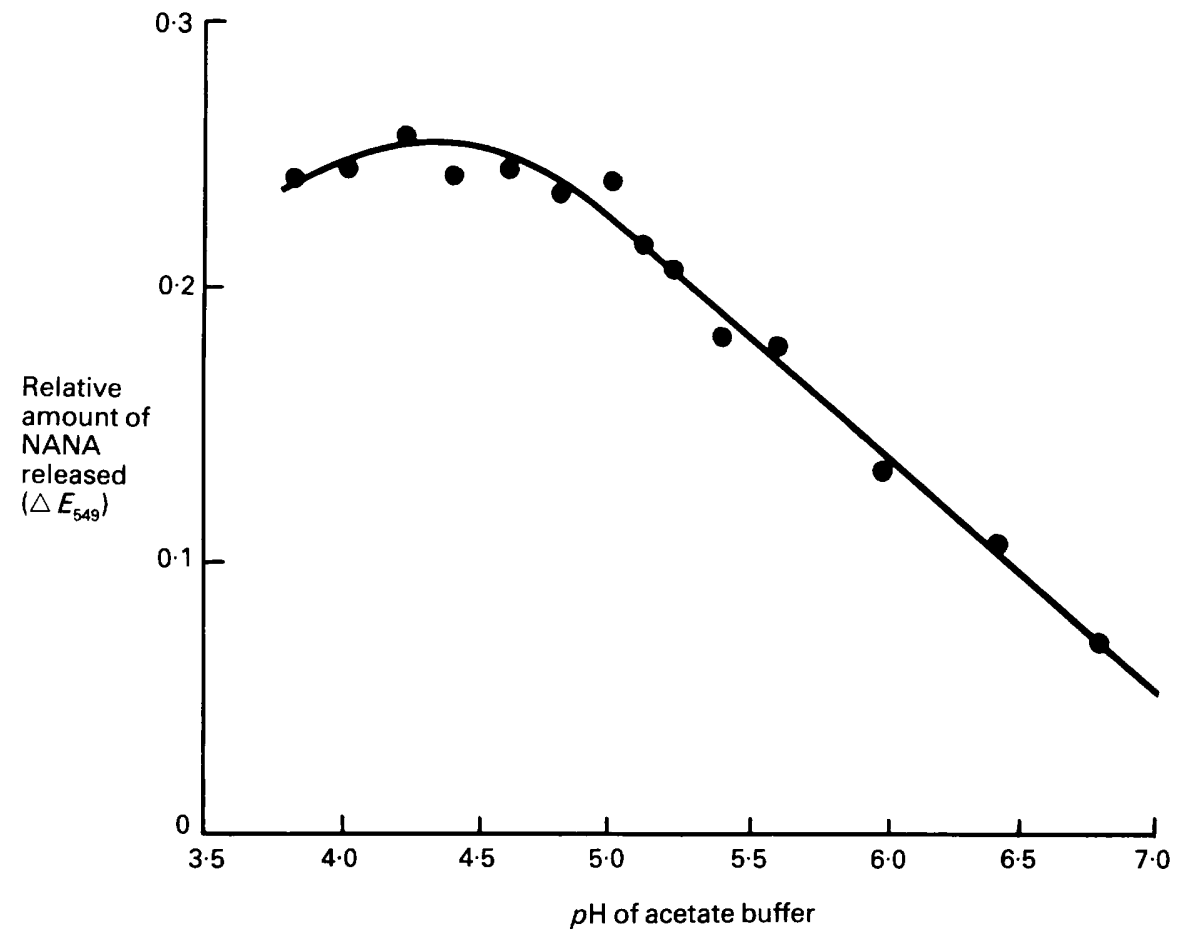

FIG.-Effect of $p \mathrm{H}$ on the assay for the neuraminidase of $\boldsymbol{B}$. fragilis. Cell extract of $\boldsymbol{B}$. fragilis strain NCTC9344 incubated with substrate FVII in sodium-acetate buffers.

buffer at this $p \mathrm{H}$ was therefore used in our tests for neuraminidase production by other Bacteroidaceae. Direct measurement of $p \mathrm{H}$ in equivalent test mixtures showed that the actual $p \mathrm{H}$ values might be $0 \cdot 2-0 \cdot 3$ units higher, but they did not vary during incubation of the tests; thus the $p \mathrm{H}$ optimum for $B$. fragilis neuraminidase is likely to be about $4 \cdot 5$.

Table II shows that the addition of $\mathrm{Ca}^{2+}$ did not affect the assay for $B$. fragilis neuraminidase. The addition of $1 \mathrm{~mm}$ EDTA did not inhibit the enzyme and even 5 mM EDTA reduced the assay value by about one third only. $\mathrm{Ca}^{2+}$ was not added as a routine to our assays for neuraminidase production by Bacteroides strains.

\section{Production of neuraminidase by species of the Bacteroides fragilis group}

Table III shows the results of measuring neuraminidase produced by various species of the $B$. fragilis group. The strains were grown for $48 \mathrm{~h}$ in DB and PPW5 broths and cell extracts were tested for neuraminidase activity. In general these organisms grew better in DB than PPW5 broth but neuraminidase-positive strains usually produced greater activity in PPW5. All the strains of $B$. fragilis and $B$. vulgatus produced large amounts of neuraminidase in both media, and the strains of $B$. distasonis and $B$. ovatus were also clearly positive. 
TABLE II

Effect of $\mathrm{Ca}^{2+}$ and EDTA on the assay of neuraminidase from B. fragilis NCTC9344

\begin{tabular}{cc}
\hline $\begin{array}{c}\text { Concentration of added } \mathrm{Ca}^{2+} \text { or } \\
\text { EDTA in reaction mixture* }\end{array}$ & $\begin{array}{c}\text { Result of neuraminidase assay } \\
\left(E_{549} \dagger\right.\end{array}$ \\
\hline $3 \mathrm{~mm} \mathrm{Ca}^{2+}$ & 0.186 \\
$1 \mathrm{mM} \mathrm{Ca} \mathrm{Ca}^{2+}$ & $0 \cdot 171$ \\
None added & 0.188 \\
1mM EDTA & 0.171 \\
5mM EDTA & 0.118 \\
\hline
\end{tabular}

* See Methods for reaction mixtures.

+ The spectrophotometric value $\left(E_{549}\right)$ is an average result obtained from duplicate 15 -min assay readings corrected by subtraction of the values for the corresponding substrate and enzyme controls.

All strains of $B$. thetaiotaomicron produced neuraminidase well in PPW5 but production in DB varied. Strain NCTC10582 was cultured in DB on four occasions; neuraminidase assays were twice positive $(+$ and ++$)$ and twice negative. Variable results were also obtained with strain GNAB16 which was once positive $(+)$ and twice negative. By contrast, three separate cultures of each organism in PPW5 broth were consistently positive.

Results with $B$. variabilis also varied. Strain GNAB18 consistently produced neuraminidase. Strain VPI11368 twice produced moderate amounts $(++)$ in PPW5 but failed, however, to produce detectable activity in one other PPW 5 culture and in three cultures in DB medium.

All the strains of $B$. uniformis, $B$. eggerthii and $B$. splanchnicus grew adequately but did not produce detectable neuraminidase in either medium.

\section{Neuraminidase production by other Bacteroides species}

The results of tests with other Bacteroides species are shown in table IV. All strains grew adequately in DB and most also grew well in BM medium. Many of these strains grew very poorly or not at all in PPW5 broth and so were not tested for neuraminidase production in this medium.

The three strains of $B$. melaninogenicus ss. melaninogenicus and the single strain of $\boldsymbol{B}$. melaninogenicus ss. levii produced neuraminidase. Production by strain WPH67 varied; it twice gave ++ activity in DB medium but was negative on another occasion and was twice negative in BM medium. The other strains were consistently positive in both media. By contrast the five strains of $B$. melaninogenicus ss. intermedius were negative in both media.

The strains of $B$. oralis and $B$. bivius were neuraminidase positive while $B$. ruminicola, $B$. disiens, $B$. asaccharolyticus and $B$. corrodens were all negative in both media. The $B$. corrodens strains did not grow well in BM broth; they were also grown and found to be negative in PPW5 medium.

Four strains of $B$. ochraceus produced neuraminidase well in DB, but production was very unreliable in BM and PPW5 media. Strain 79B produced trace amounts on three occasions in DB and once in BM broth. Strain VP12845 produced a trace of activity in only one of three cultures in DB and 
TABLE III

Production of neuraminidase by organisms of the Bacteroides fragilis group grown in broth media

\begin{tabular}{|c|c|c|c|c|}
\hline \multirow{2}{*}{$\begin{array}{l}\text { Test organism: } \\
\text { strain no. }\end{array}$} & \multicolumn{2}{|c|}{ Growth* in } & \multicolumn{2}{|c|}{$\begin{array}{l}\text { Relative amount of neuraminidase } \\
\text { activity in culture product } \dagger\end{array}$} \\
\hline & DB & PPW5 & DB & PPW5 \\
\hline \multicolumn{5}{|l|}{ B. fragilis } \\
\hline NCTC 9343 & +++ & $++t$ & + & +++ \\
\hline NCTC 9344 & $++t$ & $++t$ & +++ & $+t+$ \\
\hline WPH 1 & +++ & $++t$ & +++ & $+t+$ \\
\hline WPH 12 & +++ & +++ & +++ & $++t$ \\
\hline WPH21 & $++t$ & $+t+$ & $++t$ & +++ \\
\hline \multicolumn{5}{|l|}{ B. vulgatus } \\
\hline NCTC10583 & +++ & +++ & +++ & +++ \\
\hline GNAB 9 & +++ & +++ & ++ & +++ \\
\hline GNAB29 & +++ & $++t$ & ++ & +++ \\
\hline \multicolumn{5}{|l|}{ B. distasonis } \\
\hline ATCC8503 & + & ++ & + & ++ \\
\hline GNAB26 & ++ & + & ++ & +++ \\
\hline GNAB39 & ++ & + & ++ & $+t+$ \\
\hline \multicolumn{5}{|l|}{ B. ovatus } \\
\hline ATCC 8483 & +++ & $+t+$ & + & ++ \\
\hline WPH207 & +++ & $++t$ & \pm & $+t$ \\
\hline \multicolumn{5}{|l|}{ B. thetaiotaomicron } \\
\hline NCTC 10582 & +++ & ++ & V & $+t+t$ \\
\hline GNAB1 & +++ & $+t$ & ++ & $t+t$ \\
\hline GNAB2 & +++ & ++ & ++ & +++ \\
\hline GNAB7 & +++ & ++ & \pm & +++ \\
\hline GNAB11 & $++t$ & $+t$ & ++ & +++ \\
\hline GNAB16 & ++ & + & V & $++\ddagger$ \\
\hline GNAB20 & +++ & ++ & ++ & +++ \\
\hline \multicolumn{5}{|l|}{ B. variabilis } \\
\hline VPI11368 & +++ & ++ & $-\ddagger$ & V \\
\hline GNAB18 & $++t$ & ++ & $+\ddagger$ & $+++\ddagger$ \\
\hline \multicolumn{5}{|l|}{ B. uniformis } \\
\hline ATCC 8492 & +++ & $++t$ & - & - \\
\hline VPI11227 & +++ & ++ & - & - \\
\hline GNAB42 & $+t+$ & $++t$ & - & - \\
\hline \multicolumn{5}{|l|}{ B. eggerthii } \\
\hline NCTC11155 & ++ & + & - & - \\
\hline GNAB21 & $+t+$ & + & - & - \\
\hline GNAB23 & $+t+$ & ++ & - & - \\
\hline GNAB24 & ++ & + & - & - \\
\hline GNAB41 & $+t$ & + & - & - \\
\hline GNAB43 & +++ & $+t$ & - & - \\
\hline \multicolumn{5}{|l|}{ B. splanchnicus } \\
\hline NCTC10825 & +++ & +++ & - & - \\
\hline NCTC10826 & +++ & +++ & - & - \\
\hline
\end{tabular}

* See Methods for assessment of growth. DB= Digest broth; PPW5=Proteose peptone water.

+ Cell extract from 48-h culture in stated medium was tested. See Methods for grading of neuraminidase activity. $V=$ variable results in different experiments (see text).

$\ddagger$ Result confirmed in repeat culture. 


\section{TABLE IV}

Production of neuraminidase by strains of various Bacteroides species grown in broth media

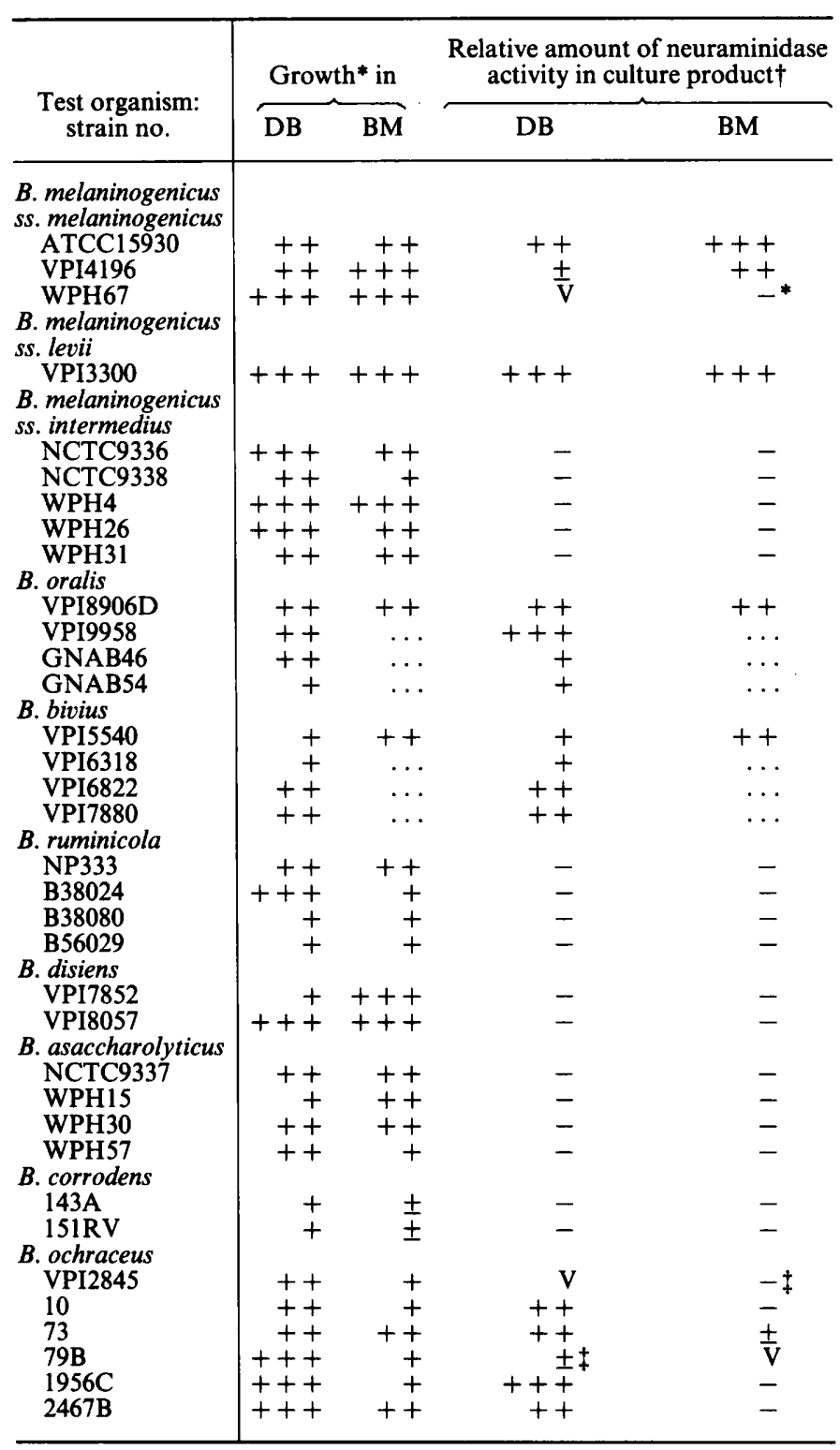

* See Methods for assessment of growth. ...=not tested; DB=digest broth; BM= BM broth.

$\uparrow$ Cell extract from culture in stated medium was tested. See Methods for grading of neuraminidase activity; . . = not tested. $V=$ variable results in different experiments (see text).

$\ddagger$ Result confirmed in repeat culture. 
was consistently negative in BM and PPW5 cultures. The difficulty in demonstrating neuraminidase activity in these cultures may be partly explained by the presence of small amounts of NANA-destroying activity in the cell extract of several of the B. ochraceus cultures.

\section{Production of neuraminidase by Fusobacterium and Leptotrichia species}

Table V shows the results when eight strains of Fusobacterium species and one of Leptotrichia buccalis were grown in DB and PPW5 media. In general they grew well in DB and less well in PPW5. The two strains that grew poorly in PPW5 were also grown and tested in BM medium. Cell extracts of all cultures were neuraminidase negative.

TABLE V

Tests for production of neuraminidase by Fusobacterium and Leptotrichia species grown in broth media

\begin{tabular}{|c|c|c|c|c|}
\hline \multirow{2}{*}{$\begin{array}{l}\text { Test organism: } \\
\text { strain no. }\end{array}$} & \multicolumn{2}{|c|}{ Growth* in } & \multicolumn{2}{|c|}{$\begin{array}{l}\text { Relative amount of neuraminidase } \\
\text { activity in culture product } \dagger\end{array}$} \\
\hline & $\mathrm{DB}$ & PPW5 & $\mathrm{DB}$ & PPW5 \\
\hline \multicolumn{5}{|l|}{ F. necrophorum } \\
\hline NCTC10575 & +++ & ++ & - & - \\
\hline NCTC10576 & ++ & + & - & - \\
\hline NCTC10577 & ++ & + & - & - \\
\hline $\begin{array}{l}\text { F.polymorphum } \\
\text { (F.nucleatum) }\end{array}$ & & & & \\
\hline NCTC 10562 & +++ & + & - & - \\
\hline WPH142 & ++ & + & - & - \\
\hline WPH160 & ++ & \pm & - & $\cdots$ \\
\hline $\begin{array}{l}F . \text { necrogenes } \\
\text { NCTC } 10723\end{array}$ & & & & \\
\hline $\begin{array}{l}\text { NCTCl0723 } \\
\text { F. varium }\end{array}$ & + & + & - & - \\
\hline $\begin{array}{l}\text { NCTC10560 } \\
\text { Narum }\end{array}$ & ++ & + & - & - \\
\hline L. buccalis & & & & \\
\hline NCTC10249 & ++ & - & - & $\cdots$ \\
\hline
\end{tabular}

* See Methods for assessment of growth. DB=digest broth; PPW5 = proteose peptone water.

$\dagger$ Cell extract from culture in stated medium was tested. See Methods for grading of neuraminidase activity. $\ldots=$ Not tested.

\section{DisCUSSION}

Neuraminidase is produced as an extracellular enzyme in culture supernates by Vibrio cholerae and Clostridium perfringens, but is cell-associated in other species, e.g., Klebsiella aerogenes and Pasteurella multocida (see Rosenberg and Schengrund, 1976). Our previous studies confirmed that clostridial neuraminidases are essentially extracellular, although some more enzyme could be released by ultrasonic disintegration of the cells (Fraser and Collee, 1975; Fraser, 1978). By contrast, the results presented in table I show that the 
neuraminidase of $B$. fragilis is predominantly cell associated, with only small amounts detectable in the supernates of 48-h cultures.

We have adapted our clostridial neuraminidase-assay techniques for use with cell extracts of $B$. fragilis and other Bacteroidaceae. The $p \mathrm{H}$ optimum for neuraminidases may vary considerably with different buffer systems and different substrates (Fraser and Smith, 1975; Rosenberg and Schengrund, 1976) but our standard assay with human glycoprotein substrate FVII with acetate buffer at $p \mathrm{H} 5.1$ also gave good results with the $B$. fragilis enzyme (see the figure). The neuraminidase produced by certain species, e.g., $V$. cholerae, is calcium dependent but added $\mathrm{Ca}^{2+}$ is not required in our assays for the enzyme produced by clostridia (Fraser, 1978) or Bacteroides species (table II).

Many of the Bacteroidaceae are nutritionally fastidious and do not generally grow well in fluid media even with growth supplements and meticulous anaerobic technique. The three media used in the present study were chosen for their ability to support good enzyme production by neuraminidase-positive species and also to allow good growth of a wide range of gram-negative anaerobes. DB medium allowed adequate growth of all species tested but did not always allow the best production of neuraminidase. Some of the $B$. fragilis group of organisms produced more enzyme in PPW5 broth; however, this medium did not support adequate growth of several other species, even when incubation was extended to $96 \mathrm{~h}$. A few of these strains produced more enzyme in BM broth than in DB medium, but there were also clear exceptions. Neuraminidase-positive strains generally produced the enzyme in each of the two media in which they were grown, but production by a few varied or did not take place in one or other (see tables III and IV). The purity of all cultures was carefully tested by subculture from the test culture. Neuraminidase production has been shown to be inducible in certain species (Nees and Schauer, 1974; Rosenberg and Schengrund, 1976) but we have not been able to identify specific inducing conditions that might explain the variations observed in this study between different media or different batches of the same medium.

Because no single medium consistently supported optimum production by neuraminidase-positive strains, other strains were tested in at least two media that supported adequate growth. All cell extracts were tested in assays incubated for $24 \mathrm{~h}$ before being classed as neuraminidase negative.

The neuraminidase assay depends upon detection of NANA released from the glycoprotein substrate by the enzyme. Some organisms also produce an aldolase (NAN-aldolase) that may destroy the released NANA and this might give false negative results in neuraminidase assays. The NAN-aldolase of clostridia remains cell associated and does not interfere with assays for neuraminidase in culture supernates, although it may reduce the sensitivity of assays with cell extracts (Fraser and Collee, 1975). Müller and Werner (1970b), using a paper chromatographic method, reported the presence of NAN-aldolase in several species of Bacteroides, including B. fragilis, and Müller (1973) also found that a strain of Fusobacterium polymorphum produced the aldolase. We have not assayed directly for NAN-aldolase (Brunetti, Swanson and Roseman, 1963; Nees et al., 1976) but we have shown that there is negligible NANA- 
destroying activity in the cell extracts of the neuraminidase-positive $B$. fragilis NCTC9344 and in the cell extracts of the various cultures that gave low values or negative results in neuraminidase assays. Very few of these cell extracts reduced the assay value for added NANA by as much as $10-20 \%$ during $24-\mathrm{h}$ incubation under conditions equivalent to those of the neuraminidase assay. This amount of NANA destruction would not appreciably reduce the ability of the assay to detect small amounts of neuraminidase. Several of the B. ochraceus cell extracts reduced the added NANA by about $40 \%$ in $24 \mathrm{~h}$ and this could have contributed to our difficulty in demonstrating neuraminidase production consistently in this group.

The classification of the Bacteroidaceae has been much refined in the past decade. Current schemes of classification are based mainly on the biochemical activities of the organisms (Holdeman and Moore, 1974; Holdeman, Cato and Moore, 1977). The strains used in the present study have been characterised carefully by the methods used in this laboratory, including gas-liquid chromatography (Duerden et al., 1976; Deacon et al., 1978; Duerden et al., 1980). The former subspecies of $B$. fragilis are now given separate species status, and $B$. thetaiotaomicron is further subdivided into the species $B$. thetaiotaomicron, $B$. eggerthii, and $B$. uniformis. Strain ATCC8492, originally the reference strain of $B$. thetaiotaomicron, is now classified as B. uniformis. Werner (1974) demonstrated that sugar fermentation tests discriminated reliably between the various species in this group; he further distinguished $B$. variabilis from $B$. uniformis by differences in fermentation of rhamnose and trehalose.

The classification of the $B$. oralis- $B$. melaninogenicus group has been considerably revised in recent years, with less emphasis placed on pigment production as the criterion for classifying strains as $B$. melaninogenicus. Because of the basic difference in sugar utilisation, B. melaninogenicus ss. asaccharolyticus has been given separate species status as $B$. asaccharolyticus, while $B$. melaninogenicus is now divided into the subspecies melaninogenicus, levii and intermedius. There has been some debate about the classification of $B$. oralis strains. Strain ATCC15930, originally a reference strain of $B$. oralis, is now reclassified as $B$. melaninogenicus ss. melaninogenicus (Holbrook and Duerden, 1974). Strain NP333, previously described as $B$. oralis, is now reallocated to B. ruminicola. Strains of B. ochraceus differ from other Bacteroidaceae in that they require $\mathrm{CO}_{2}$ for growth but are not strict anaerobes (Holbrook, Duerden and Deacon, 1977). It has recently been proposed that they should be reclassified in the new genus Capnocytophaga (Newman et al., 1979; Williams, Hollis and Holdeman, 1979).

Our results for neuraminidase production by Bacteroides are consistent within each species and tend to confirm the present classification. Within the $B$. fragilis group, $B$. fragilis, B. vulgatus, $B$. distasonis and $B$. ovatus were all neuraminidase positive. Seven strains of $B$. thetaiotaomicron were positive while six strains of the closely related $B$. eggerthii were negative. The $B$. variabilis strains were distinguished from the $B$. uniformis strains by their production of the enzyme. Within the $B$. oralis- $B$. melaninogenicus group, $B$. oralis and $B$. melaninogenicus ss. melaninogenicus were neuraminidase positive 
while ss. intermedius and $B$. ruminicola were negative; the single strain of $B$. melaninogenicus ss. levii tested was neuraminidase positive. B. bivius produced the enzyme, while the closely related $B$. disiens did not. The asaccharolytic species, $B$. asaccharolyticus and $B$. corrodens, were both negative. The six strains of $B$. ochraceus tested could all produce neuraminidase although it was difficult to define conditions allowing reliable production.

Production of neuraminidase by Bacteroides species was studied by Müller and Werner (1970b; Werner and Müller, 1971). These studies depended primarily on observing the electrophoretic changes in serum proteins in the culture medium after incubation for 2-19 days, but were also supported by paper chromatography of neuramin-lactose and its split products. They found that all of 24 strains of $B$. fragilis produced the enzyme, but only six of $11 B$. vulgatus, three of five $B$. distasonis and six of eight $B$. thetaiotaomicron. With our assay procedures, testing cell extracts of the cultures, all the strains of these species examined were neuraminidase positive. At least one of their negative $B$. thetaiotaomicron strains (ATCC8492) is now reallocated to B. uniformis; this strain was negative in our assays also. Their findings with other Bacteroides species are in broad agreement with our present results: B. ovatus ATCC8483, three strains of $B$. oralis (including ATCC15930) and one strain of Leptotrichia innominata var. ochracea ( $B$. ochraceus) were positive, and single strains of $B$. asaccharolyticus (NCTC9337) and of $B$. putredinis were negative.

Müller and Werner (1970a) also studied pus from a $B$. fragilis abscess and showed that neuraminidase was produced in vivo. They suggested that the neuraminidase might play a role in the pathogenicity of $B$. fragilis, demonstrating that it is produced in greater amounts and has a broader spectrum of action against serum glycoproteins than the enzyme produced by other Bacteroides species. B. fragilis is now an accepted pathogen; although it is only a minor component of the anaerobic gut or vaginal flora it is much the most common Bacteroides species isolated from clinical infections (Duerden, $1980 a$ and $b$ ). The pathogenic potential of other Bacteroides species is much less clearly understood at present; it will be interesting to note whether there is any correlation with their ability to produce neuraminidase.

Fukui, Fukui and Moriyama (1971) failed to detect neuraminidase in four strains of Fusobacterium species and two of Leptotrichia buccalis isolated from the mouth, nor could we detect the enzyme in cell extracts of the strains that we examined. However, Werner and Müller (1971) detected weak neuraminidase activity against plasma proteins in two of 10 strains of Sphaerophorus necrophorum ( $F$. necrophorum), two of three $S$. varium ( $F$. varium) including NCTC10560, and one of seven other Fusobacterium strains. Müller (1973) isolated a strain of $F$. polymorphum from the throat of a patient with actinomycosis; it showed strong neuraminidase activity when first isolated but this declined to a low level during subsequent laboratory passage. Müller (1973, 1974) has argued that neuraminidase plays a role in the pathogenicity of various organisms and that in some cases its production may be induced in vivo. The Fusobacterium strains that we found to be neuraminidase negative have been maintained in laboratory culture for some years and it remains 
possible that they have lost the ability to produce the enzyme during storage.

Solovev et al. (1972) found tests for neuraminidase production of value for studies of vibrio taxonomy and our previous studies suggested that they might also help to differentiate some closely related clostridia, e.g., $C$. sordellii and $C$. bifermentans (Fraser, 1978). The taxonomy of the fusobacteria is still being debated (see Duerden et al., 1980) and our failure to demonstrate neuraminidase in any of the strains tested is unlikely to be of assistance. However, the results of our tests in Bacteroides species are consistent and conform with the latest classifications (Holdeman et al., 1977; Duerden et al., 1980). They help to discriminate between several closely related species that are otherwise distinguished only by a small number of sugar fermentation reactions, e.g., between the species previously included in $B$. thetaiotaomicron, and between various species of the $B$. oralis $-B$. melaninogenicus group. Tests for neuraminidase production would therefore be a valuable addition to the range of biochemical tests currently used in classification of Bacteroides organisms.

We thank Professor J. G. Collee for constant advice and encouragement; Miss M. Byrne, $\mathrm{Mr}$ G. Hay and Mr G. Henderson for skilled technical assistance; and Dr J. G. Watt, Scottish National Blood Transfusion Service, Protein Fractionation Centre, Ellen's Glen Road, Edinburgh EH17 7QT, for supplies of FVII substrate.

\section{REFERENCES}

Brunetti, P., Swanson, A. AND Roseman, S. 1963. Enzymatic determination of sialic acids. $\mathrm{N}$-Acylneuraminic acid $\rightleftarrows \mathrm{N}$-Acyl-D-mannosamine + pyruvate. In Methods in enzymology, edited by S. P. Colowick and N. O. Caplan, Academic Press, New York and London, vol. 6, p. 465.

COLleE, J. G. 1965. The relationship of the haemagglutinin of Clostridium welchii to the neuraminidase and other soluble products of the organism. J. Path. Bact., 90, 13.

Cruickshank, R., Duguid, J. P., Marmion, B. P. and Swain, R. H. A. 1975. Medical microbiology, 12th ed., Churchill Livingstone, Edinburgh, vol. 2, p. 111.

Deacon, A. G., Duerden, B. I. AND Holbrook, W. P. 1978. Gas-liquid chromatographic analysis of metabolic products in the identification of Bacteroidaceae of clinical interest. $J$. med. Microbiol., 11, 81 .

DrZeniEk, R. 1972. Viral and bacterial neuraminidases. Curr. Top. Microbiol. Immun., 59, 35.

DuERDEN, B. I. 1980a. The isolation and identification of Bacteroides spp. from the normal human faecal flora. J. med. Microbiol., 13, 69.

DUERDEN, B. I. $1980 \mathrm{~b}$. The isolation and identification of Bacteroides spp. from normal human vaginal flora. J. med. Microbiol., 13, 79.

Duerden, B. I., Collee, J. G., Brown, R., Deacon, A. G. and Holbrook, W. P. 1980. A scheme for the identification of clinical isolates of gram-negative anaerobic bacilli by conventional bacteriological tests. J. med. Microbiol., 13, 231 .

Duerden, B. I., HolbrooK, W. P., COLLEE, J. G. AND WATT, B. 1976. The characterization of clinically important gram-negative anaerobic bacilli by conventional bacteriological tests. J. appl. Bact., 40, 163.

FInEgold, S. M. 1977. Anaerobic bacteria in human disease, Academic Press, New York.

FRASER, A. G. 1978. Neuraminidase production by clostridia. J. med. Microbiol., 11, 269.

Fraser, A. G. AND ColleE, J. G. 1975. The production of neuraminidase by food-poisoning strains of Clostridium welchii (C. perfringens). J. med. Microbiol., 8, 251. 
Fraser, A. G. AND Smith, J. K. 1975. Preparation of a glycoprotein fraction from pooled human plasma and its evaluation as a substrate for the assay of Clostridium welchii ( $C$. perfringens) neuraminidase. J. med. Microbiol., 8, 235.

FukUI, K., FukUI, Y. AND MorIYAma, T. 1971. Neuraminidase activity in some bacteria from the human mouth. Archs oral Biol., 16, 1361.

HolbroOK, W. P. AND DuERDEN, B. I. 1974. A comparison of some characteristics of reference strains of Bacteroides oralis with Bacteroides melaninogenicus. Archs oral Biol., 19, 1231.

HolbrooK, W. P., DuERden, B. I. AND Deacon, A. G. 1977. The classification of Bacteroides melaninogenicus and related species. J. appl. Bact., 42, 259.

Holdeman, L. V., Cato, E. P. AND Moore, W. E. C. 1977. Anaerobe laboratory manual, 4th ed., Virginia Polytechnic Institute and State University, Blacksburg, Virginia.

Holdeman, L. V. AND MoORE, W. E. C. 1974. Bacteroidaceae. In Bergey's manual of determinative bacteriology, 8th ed., edited by R. E. Buchanan and N. E. Gibbons, Williams \& Wilkins, Baltimore, p. 384 .

MÜLLER, H. E. 1973. The occurrence of neuraminidase and acylneuraminate pyruvate-lyase in Fusobacterium polymorphum and their pathogenetic role. Zentbl. Bakt. ParasitKde, I. Abt. Orig., 224, 212 (in German).

MÜLLER, H. E. 1974. Neuraminidases of bacteria and protozoa and their pathogenetic role. Behring Inst. Mitt., no. 55, p. 34.

MülleR, H. E. AND WeRNeR, H. 1970a. Neuraminidase as a pathogenic factor in an abscess caused by Bacteroides fragilis. Z. med. Mikrobiol. Immun., 156, 98 (in German).

MÜLLER, H. E. AND WERNER, H. 1970b. In vitro studies in the occurrence of neuraminidase in Bacteroides species. Pathologia Microbiol., 36, 135 (in German).

NEES, S. AND SCHAUER, R. 1974. Induction of neuraminidase from Clostridium perfringens and the cooperation of this enzyme with acylneuraminate pyruvate-lyase. Behring Inst. Mitt., no. 55 , p. 68.

Nees, S., Schauer, R., Mayer, F. AND Ehrlich, K. 1976. Purification and characterisation of $\mathrm{N}$-acetylneuraminate lyase from Clostridium perfringens. Hoppe-Seyler's Z. physiol. Chem., 357, 839.

Newman, M. G., Sutter, V. L., Pickett, M. J., Blachman, U., Greenwood, J. R., Grinenko, V. AND CITRON, D. 1979. Detection, identification, and comparison of Capnocytophaga, Bacteroides ochraceus, and DF-1. J. clin. Microbiol., 10, 557.

Rosenberg, A. AND Schengrund, C.-L. 1976. Sialidases. In Biological roles of sialic acid, edited by A. Rosenberg and C.-L. Schengrund, Plenum Press, New York p. 295.

Solovev, V. D., Domaradsky, I. V., Shimanyuk, N. Ya., Bichul, K. G. and KuREnNaya, I. I. 1972. Function of neuraminidase in Vibrio taxonomy. Bull. exp. Biol. Med. U.S.S.R., 73, 61.

WERNER, H. 1974. Differentiation and medical importance of saccharolytic intestinal Bacteroides. Arzneimittel-Forsch., 24, 340.

WERNER, H. AND MÜLLER, H. E. 1971. Immunelectrophoretic studies on the action of Bacteroides, Fusobacterium, Leptotrichia and Sphaerophorus species on human plasma proteins. Zentbl. Bakt. ParasitKde, I. Abt. Orig., 216, 96 (in German).

Williams, B. L., Hollis, D. and Holdeman, L. V. 1979. Synonymy of strains of Center for Disease Control group DF-1 with species of Capnocytophaga. J. clin. Microbiol., 10, 550. 